\title{
Higher Perceived Design Thinking Traits and Active Learning in Design Courses Motivate Engineering Students to Tackle Energy Sustainability in Their Careers
}

\author{
Julie Milovanovic ${ }^{1}\left(\mathbb{D}\right.$, Tripp Shealy ${ }^{1, *(1)}$ and Andrew Katz ${ }^{2}$ \\ 1 Department of Civil and Environmental Engineering, Virginia Tech, Blacksburg, VA 24061, USA; \\ jmilovanovic@vt.edu \\ 2 Department of Engineering Education, Virginia Tech, Blacksburg, VA 24061, USA; akatz4@vt.edu \\ * Correspondence: tshealy@vt.edu
}

\section{check for} updates

Citation: Milovanovic, J.; Shealy, T.; Katz, A. Higher Perceived Design Thinking Traits and Active Learning in Design Courses Motivate Engineering Students to Tackle Energy Sustainability in Their Careers. Sustainability 2021, 13, 12570. https://doi.org/10.3390/ su132212570

Academic Editors: Vicky Lofthouse and Ksenija Kuzmina

Received: 6 October 2021

Accepted: 10 November 2021

Published: 14 November 2021

Publisher's Note: MDPI stays neutral with regard to jurisdictional claims in published maps and institutional affiliations.

Copyright: (c) 2021 by the authors. Licensee MDPI, Basel, Switzerland. This article is an open access article distributed under the terms and conditions of the Creative Commons Attribution (CC BY) license (https:// creativecommons.org/licenses/by/ $4.0 /)$.
Abstract: Engineers play an important role in implementing the Sustainable Development Goals defined by the United Nations, which aim to provide a more sustainable environment for future generations. Through design thinking, creativity, and innovation, sustainable engineering solutions can be developed. Future engineers need to acquire skills in their engineering curriculum to feel equipped to address sustainable design challenges in their career. This paper focuses on the impact of perceived design thinking traits and active learning strategies in design courses to increase senior engineering students' motivation to engage in energy sustainability in their career. A national survey was distributed to senior engineering students in the United States $(n=4364)$. The survey asked students about their motivation to engage in sustainable design, their perceived design thinking traits (i.e., integrative feedback, collaboration), and if they experienced active learning strategies in design courses (i.e., learning by doing). The results highlight that higher perceived design thinking ability increases senior engineering students' interests in designing solutions related to energy sustainability. Active learning experiences positively influence senior engineering students' interests in designing solutions related to energy sustainability. These findings show the importance of teaching design thinking in engineering courses to empower future engineers to address sustainable challenges through design and innovation.

Keywords: design thinking traits; active learning; sustainable design; engineering education

\section{Introduction}

To align with the United Nations (UN) 2020 Sustainable Development Goals (SDG) [1], engineers need to innovate in their current engineering practices. Design skills and creativity are a prerequisite to invent sustainable engineering solutions. Sustainable design requires a systems thinking perspective, coordination across a multidisciplinary team, focus on long-term outcomes rather than just immediate gains, and creativity to develop new design solutions that equally balance societal benefit, economic growth, and environmental regeneration [2-5].

Teaching design in the engineering curriculum [6,7] is key to provide future engineers the abilities to address society's challenges through sustainable design. Design innovations at a systems' level will offer solutions to ensure the sustainability of future engineering developments, such as infrastructure [2]. Over the past several decades, engineering curriculums have put more emphasis on teaching design skills to engineering students [8-10] to go beyond a mere technical approach to problem solving in engineering. For example, the Conceive-Design-Implement-Operate teaching framework, adapted by more than 150 institutions across the world, recognizes design as a critical step in creating new systems and enterprises. It relies heavily on active learning methods to teach not only technical 
content but also communication and professional skills to students $[8,11]$ that align with expected professional competencies [12].

To support the development of design skills, educators need to implement active learning strategies in engineering design courses as designing encompasses tacit knowledge. Such strategies, such as project-based learning [7], are anchored in a social constructivist $[13,14]$ and experiential approach to learning [15]. In this setting, learning is sequential, involves a cyclical transformation of students' experiences, and is impacted by the social environment of the learning experience. Collaboration between students [9] and in situ experiences $[16,17]$ tend to benefit students' development of design skills. Learning design skills transposable to students' future practices is key for them to address sustainable development challenges in engineering.

In this paper, we analyze to what extent (1) perceived design thinking traits and (2) active learning strategies in design courses are connected to (3) senior engineering students' interest in designing solutions related to energy sustainability in their future career. Findings are based on a national survey of senior engineering students in the United States $(n=4364)$. We specifically focused on students' interest in designing solutions related to energy efficiency, which falls into the SDG \#7, "ensuring access to affordable and sustainable energy for all" [1]. We explored whether students with higher perceived design thinking abilities hold higher interests in designing solutions related to energy sustainability. Students' responses to questions about five design thinking traits (feedback seeking, integrative thinking, optimism, experimentalism, and collaboration) were analyzed as predictors of motivation to engage in sustainable design. We also assessed whether specific teaching strategies in design courses influenced students' interests in tackling energy sustainability challenges in their future career.

In the following section, we highlight the importance of design skills to integrate sustainability in engineering design and the challenges of teaching design in engineering. In Section 3, the research questions are stated, followed by Section 4 that describes the survey development, data collection, and analysis. The items measured through this survey, pedagogical experiences in design courses, interests in designing solutions related to energy sustainability, and perceived design thinking abilities are described. Section 5 illustrates relationships between each item and Section 6 expands our findings within the current body of work in sustainable design education, as well as implications for engineering education.

\section{Background}

\subsection{Importance of Design Thinking Skills to Integrate Sustainability in Engineering Design}

Engineering design is a goal-oriented process aimed at solving complex multidimensional problems that involve technical, economic, social, and environmental requirements $[18,19]$. Engineers rely on a set of tactical skills (knowing how), developed through experience, to address design problems in complex contexts [20]. In engineering, design thinking is a way of reasoning to address situated ill-defined design problems through processes of reframing the design problem, proposing solutions, and (re)evaluating concurrently the design requirements and the proposed design solution [21-23]. Unlike problem solving of structured problems that relies primarily on deductive reasoning, design thinking necessitates abductive reasoning and critical thinking [22,23].

According to Dym and colleagues [7], engineering design thinking skills are characterized by an ability to tolerate ambiguity and handle uncertainty, big-picture thinking, engaging in design thinking as part of a team in a social process, and being able to think and communicate in several languages of design (related to multiplicity of design fields and stakeholders involved). Studies of professionals demonstrate that design thinkers rely on a user-centered approach to design by experimenting solutions through convergent and divergent thinking and reframing the problem to expand the solution space [24,25]. Engineers need to mobilize such design thinking skills to address engineering design problems with innovative sustainable design solutions. 
The United Nations (UN) defined 17 Sustainable Development Goals (SDG) in their 2020 report [1], echoing concerns raised in the Brundtland report more than 30 years ago [26]. The 2020 UN report identifies pressing world challenges that need to be addressed by 2030 and emphasizes how essential sustainable developments remain [1]. Interdisciplinarity will help address the socio-economic crisis (i.e., social equity, food and water security, and rising poverty) and the environmental crisis (i.e., depletion of resources and climate change).

Sustainable Development Goals such as ensuring availability and sustainable management of water for all (SDG \#6), ensuring access to affordable and sustainable energy for all (SDG \#7), and taking action to combat climate change (SDG \#13) [1] point toward guidelines to meet current needs without compromising future generations to meet their own needs [26]. There is a common consensus among stakeholders in engineering regarding the importance of addressing these issues and social challenges through engineering (i.e., health, diversity, and service to communities) $[4,27,28]$.

Early phases in the design process, such as idea generation [29], offer an opportunity to integrate sustainability seamlessly in engineering solutions [2,30]. Designing sustainable solutions set higher requirements for engineers to satisfy [31,32]. Nonetheless, integrating sustainability into engineering design is essential considering the environmental crisis.

Innovations can lead to better sustainable engineering solutions. They imply an adaptation either at the product scale, the function scale, or the system scale [2]. For instance, when thinking about the unsustainability of a paper cup, a change at the product scale would be to produce it more ecologically [2]. A change at the function level could be to reuse the cup and adapt its shape to make it easy to transport, for example a collapsible traveling mug [2]. A system scale change is disruptive to existing habits. For instance, paper cups could be banned from coffee shops in place of a "mug-on-loan" alternative [2].

System-level innovations tackle sustainable issues at a global scale, challenging social and cultural assumptions to exceed a mere artifact redesign. Engineers trained in systems thinking are well suited to implement sustainable design to reach current societal needs in sustainable development [3,4]. Design thinking and systems thinking skills have to be taught in engineering curricula to provide future engineers the ability to address society's challenges through sustainable engineering solutions.

\subsection{Pedagogic Strategies to Teach Designing in Engineering}

Educating engineers to create design solutions meeting sustainability requirements is increasingly part of engineering education $[7,33]$. Changes need to occur at multiple levels, from the institution (renew organizational culture to emphasize commitment to contribute to society, solidarity, openness, and creativity) to curriculum teaching (mandatory courses in sustainable development through active learning) [34]. Teaching design for sustainability requires going beyond traditional problem-solving approaches to favor a design thinking one, through project-based learning $[6,7,35,36]$. Indeed, designing involves tactical skills (know-how) that students can acquire through project-based learning. Students must learn to use novel context-based processes that include addressing engineering problems through systems thinking [3,4], with empathy [37] while drawing on knowledge from the physical and social sciences [5].

Engineering education has put more emphasis on design teaching in the past century [10]. Teaching design necessitates teaching through applied projects, in an integrative and holistic problem-defining setting [38]. Teaching with a design thinking approach, user centered, compared to a traditional process-based one, leads to more innovation and self-efficacy from students [39,40]. For example, teaching design through hands-on and on-site urban labs places students in a user-centered approach to designing that benefits the development of their design skills while integrating sustainability [17]. For future engineers to address engineering problems through sustainable design innovations, they need to develop design thinking skills, and hence undergo learning experiences suitable to develop such it. 
Learning design thinking skills suits several types of learning: learning by doing, learning by imitation, and collaborative learning among others [41-43]. Engineering design courses promote a learning environment through a process of trial and error, by doing design. Students develop insights into how to design through the learning by doing approach [43]. Moreover, tutors take on the role of mentors, guides, coaches, and role models for students, helping them to address the design problems they face. Tutors encourage students to think about the solution they propose rather than giving them a ready-made solution [44,45]. In their study, Adams and colleagues [44] observed several recurring coaching strategies such as "scaffolding to help students articulate and evaluate their reasoning", "driving for meaning and guidance", or "suggest don't tell to let the student figure it out". They all relate to learning by doing. Through collaborations with their tutors, students also learn by imitation as they observe tutors' thinking processes [42].

Collaborative learning through a group project instead of individual ones has become the norm in design courses. Collaboration and negotiation with peers during design courses support the development of a critical and reflective view of each design proposal [46]. The implementation of a democratic culture in a design course, where individual competition is set aside in favor of better communication between peers, and between tutors and students, is beneficial to learning how to design $[47,48]$. The pedagogical strategies used in design courses influence students' development of engineering design skills. Both pedagogical strategies and curriculum content, for instance the type of engineering project, should define a suitable environment for students to learn how to design. Doing so, engineering students will acquire skills to address engineering problems with creativity and innovation, both necessary for sustainable design.

\section{Research Questions}

This study does not focus on teaching sustainable design as in [49-51]. Rather, it explores the relationship between (1) perceived design thinking traits, (2) learning strategies in design courses, and (3) the motivation to develop sustainable design solutions in one's future career. The research questions are:

1. What is the effect of senior engineering students with high perceived design thinking ability and their interests in designing solutions related to energy sustainability?

2. How do active learning strategies implemented in engineering design courses (learning by doing, learning by imitation, collaborative learning) influence senior engineering students' interests in designing solutions related to energy sustainability?

We expect engineering students with higher design thinking abilities to display a higher interest in engaging in sustainable design for energy efficiency. The assumption is that feeling equipped with design thinking skills may trigger a higher willingness to undertake sustainable design projects, as these challenges seem more achievable. We also expect that active learning strategies in design courses will have a positive effect on students' interest in designing solutions to support energy sustainability. Teaching strategies in design courses can impact how knowledge is constructed. Through learning by doing design, students can develop skills to reflect in action, using context-based knowledge instead of a technique driven approach. Mastering such skills is key to designing for a sustainable future and could increase students' motivation to do so.

\section{Materials and Methods}

\subsection{Survey Development}

To address the research questions, results from a two-round national survey of senior engineering students in the United States were analyzed. These surveys were approved by Virginia Tech's Institutional Review Board. Surveys were distributed during spring and fall 2018. The sampling frame included four-year institutions chosen from the National Center for Education Statistics institutional database. A stratified random list was created by categorizing institutions by undergraduate enrollment including small $(<5400)$, medium (5400-14,800), and large institutions $(>14,800)$. The engineering department head of each 
institution was contacted first. If institutions agreed to participate in the study, instructors were asked to distribute paper copies of the survey in their capstone courses. In total, the survey was given to students from 83 courses. Capstone instructors were allowed to access the de-identified data in exchange for their cooperation, as authorized by IRB protocol at Virginia Tech. Students who completed the survey were told the survey was not part of their course. They did not receive class credit or any type of grade for completing the survey. The survey was also anonymous.

A total sample of $n=4364$ senior engineering students were collected nationally. Male students represented $65 \%$ of the sample. Females represented $23 \%$ of the sample. The remaining $12 \%$ did not disclose gender identity. Figure 1 illustrates the participants' home ZIP codes by state. The size of dots indicates the sample size from each ZIP code. The map was created using ggplot2 [52], a package within the R statistical software [53].

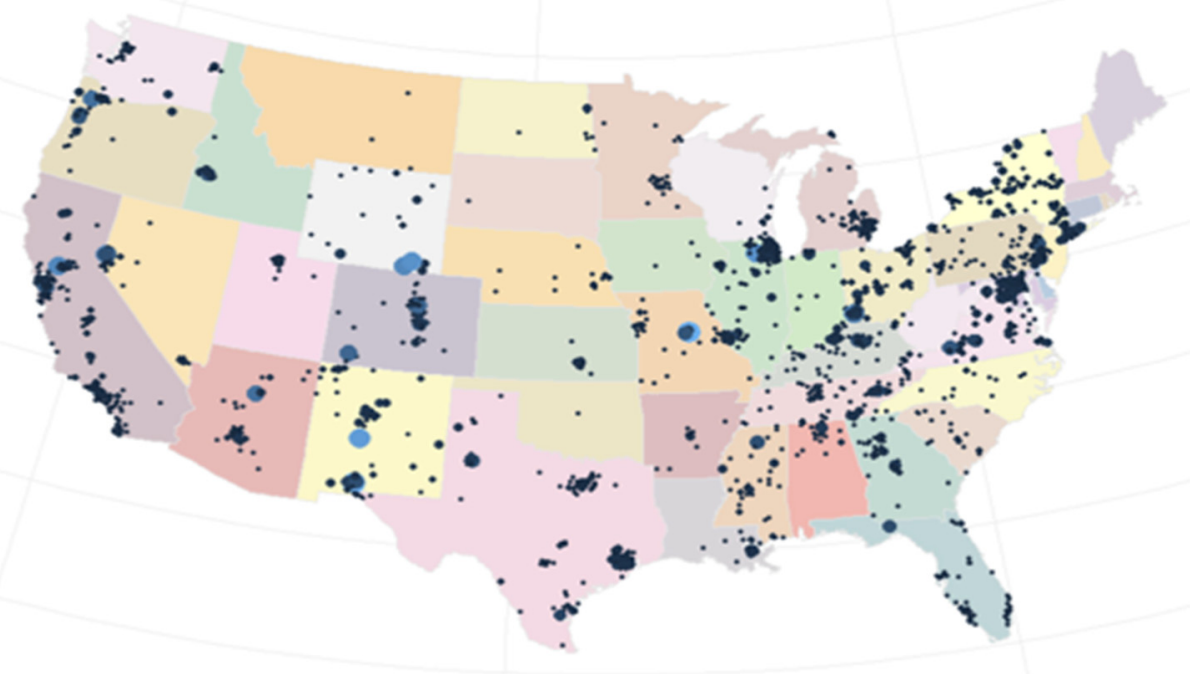

Figure 1. Participants' home locations based on home ZIP code.

The survey was categorized into six sections: (1) career goals and motivation, (2) college experiences, (3) agency, (4) climate literacy, (5) people and the planet, and (6) demographic information. It aimed to assess students' awareness and willingness to take action to address sustainable design challenges such as combating climate change (see [54] for more details). Previous work using the survey focused on the perception of technical and social issues related to climate change for civil engineers [55]. The survey was previously validated for its content and construct [54]. In this paper, results are based on the following sections of the survey: (2) college experiences, (3) agency, and (5) people and the planet.

\subsection{Measuring Interests in Designing Sustainable Solutions Related to Energy Sustainability}

To assess participants' interests in designing solutions related to energy sustainability, which was the outcome variable, we analyzed the following questions from the survey: "How interested are you in working on the following solutions in your career?" This question was asked for several outcomes: (a) redesigning conventional processes in order to minimize energy consumption; (b) developing technologies that improve energy efficiency; (c) creating ways to reduce carbon dioxide emissions and (d) working on renewable energy technologies, such as solar and wind power. The options were an anchored numeric fivepoint rating scale from 0 - "Not at all" to 4-"Very much so." To generate a score for topics related to energy sustainability, we added the four individual item responses together for a composite score ranging from 0 (if a student answered 0 to each of these items) to 16 (if a student answered 4 to each of the items). With this score ranging from 0 to 16 , we were then able to model this outcome as a continuous variable in our regression model. 
We completed a confirmatory factor analysis (CFA) using the lavaan package in R to determine if the four survey items used to generate our score factored together. The CFA model included several fit indices in accordance with Byrne's suggestions [56] including Comparative Fit Index (CFI), Tucker Lewis Index (TLI), standardized root mean square residual (SRMR), and root mean square error of approximation (RMSEA). The chi-square statistic was not a good indicator of our model fit because the sample size was greater than 400 [57]. The fit indices for the four-factor structure were CFI $=0.98, \mathrm{TLI}=0.94$, SRMR $=0.024$, and RMSEA $=0.136(\mathrm{CI}$ upper bound $=0.154, \mathrm{CI}$ lower bound $=0.119)$. The RMSEA value was above the value for moderate fit but the CFI, TLI, and SRMR indicated a good fit and appropriately meet the cutoff index [58].

\subsection{Assessing Perceived Design Thinking Traits}

The design thinking trait items are based on previous work [59]. Blizzard and colleagues validated the survey instrument described in Table 1 to measure perceived design thinking abilities [59]. Blizzard and colleagues administered their design thinking instrument in a survey titled Sustainability and Gender in Engineering (SaGE) to a national sample of 7451 first-year collegiate students from 59 U.S. institutions. After data collection, Blizzard et al. [59] conducted an exploratory factor analysis (EFA) on the design thinking instrument that revealed a five-factor structure. Blizzard et al.'s instrument initially contained 18 items, but through EFA it was reduced to a 9-item instrument [59]. Based on the theoretical framework, the five traits cover five domains of design thinking that represent the single latent variable of design thinking. Refer to Table 3 in Blizzard et al. [59] for the final EFA and details about the EFA method.

Table 1. Design thinking traits and related survey questions.

\begin{tabular}{ll}
\hline \multicolumn{1}{c}{ Design Thinking Traits Based on [24] } & \multicolumn{1}{c}{ Survey Questions } \\
\hline $\begin{array}{l}\text { Collaboration: Work with many different } \\
\text { disciplines and often have experiences in more } \\
\text { than just one field. }\end{array}$ & $\bullet \quad \begin{array}{l}\text { I hope to gain general knowledge across } \\
\text { multiple fields. }\end{array}$ \\
\hline
\end{tabular}

Experimentalism: Ask questions and adopt new approaches to problem solving.
- When problem solving, I focus on the relationships between issues.
Optimism: Do not back down from challenging problems.
- I can personally contribute to a sustainable future.

- Nothing I can do will make things better in other places on the planet.
Integrative thinking: Can analyze at a detailed and holistic level to develop novel solutions.
- I analyze projects broadly to find a solution that will have the greatest impact.

- I identify relationships between topics from different courses.
Feedback seeking: Ask questions and look for input from others to make decisions and change directions.
- I seek input from those with a different perspective from me.

- I seek feedback and suggestions for personal improvement.

Source: Design thinking survey instrument developed by [59].

Engineering design skills defined in Section 2 (see [7]) can be summarized by those five design thinking traits: collaboration, experimentalism, optimism, integrative thinking, and feedback seeking. These traits correspond to design skills identified in the industry by 
Brown and others [24,60]. They also fit into a theoretical representation of such skills. For example, collaboration or the ability to work with many different disciplines was assessed through the evaluation of the following statements: "I hope to gain general knowledge across multiple fields" and "I often learn from my classmates". Integrative thinking or the ability to analyze a design problem at a detailed and holistic level to innovate was measured through participants' rating of the following statements: "I analyze projects broadly to find a solution that will have the greatest impact" and "I identify relationships between topics from different courses". For each of the nine survey statements to evaluate engineering students' design thinking abilities, the answering options were an anchored numeric five-point rating scale from 0 - "Strongly disagree" to 4-“ Strongly agree". There are limitations to this design thinking scale, which Blizzard [59] acknowledges. For instance, other traits important for designers to possess do exist, such as creative thinking to develop innovative design solutions [61]. Furthermore, the survey items were only tested with first-year students while expertise in design influences design skills [21].

Coleman et al. [62] measured the items with the same senior engineering sample used in this study. They used confirmatory factor analysis (CFA) to determine if the five-factor structure could be applied to senior engineering students. Similar to our measure for the energy sustainability factor of survey items, Coleman et al. used CFA and several fit indices including CFI, TLI, SRMR, and RMSEA. The fit indices for the five-factor structure from Coleman et al. [62] were CFI $=0.966$, TLI $=0.932, \mathrm{SRMR}=0.036$, and $\mathrm{RMSEA}=0.063$ (CI upper bound $=0.073, \mathrm{CI}$ lower bound $=0.053$ ). Coleman et al. [62] also conducted discriminant validity checks, finding that when developing a future measure of design thinking, the scale should include more items to distinguish integrative thinking, collaboration, and experimentalism as discrete factors.

In this study, the survey items and their connection to design thinking traits used in their original form published from Blizzard et al. [59] and Coleman et al. [62] were used. However, we used the items independently, rather than factored together. This removed the need for a CFA because each item was individually used as a predictor of a student's energy sustainability scale score.

\subsection{Assessing Pedagogic Strategies Implemented in Engineering Design Courses}

The section from the survey that captured participants' learning experiences in their senior engineering design course stated: "Indicate how often the following occurred in your most recent engineering design course". This section asked about outcomes that can be grouped by active learning strategies used in design courses. Students were asked about the frequency of the following pedagogic experiences:

- Learning by imitation: "The teacher did demonstrations";

- Learning by doing: "We spent time doing individual work in class" and "We worked on labs or projects";

- Collaborative learning: "We spent time doing small group activities", "Classmates taught each other", and "Whole-class discussions were held".

Participants' options were anchored on a scale from "Never", "Rarely", "Monthly", "Weekly", to "Daily".

\subsection{Data Analysis}

Missing data were imputed using multivariate imputation by chained equations (MICE) with predictive mean matching [63] as implemented in the mice package [64] within the R statistical software [53]. To account for the large number of covariates imputed in the original dataset, we imputed 40 datasets as recommended in van Buuren [64]. All covariates in the dataset were imputed except student demographic characteristics or other nominal variables where this approach could be inappropriate.

To analyze the dataset, we used a Bayesian modeling framework with uninformative priors with the brms package in $\mathrm{R}$ [65]. This approach appeared relevant as it provides flexibility in modeling individual non-linear predictor variables. As noted above, each 
covariate was marked on a five-point ordinal scale. Such a scale can be inconsistent with assumptions for standard linear regression models which assume a constant $\mathrm{X}$-unit change in the outcome for a one-unit change in the predictor (where $X$ is the value of the regression coefficient in the linear model). Instead of making this strong assumption, we made a weaker assumption that changing from 0 to 1 (or "Never" to "Rarely" in the case of the items used here) only corresponded to a monotonic change. In other words, we assumed that going from 0 to 1 or 2 to 3 would produce a change in the same direction but the strength (or magnitude) of that change would not be constant when going from "Never" to "Rarely" or "Weekly" to "Daily". Overall, this approach offers a more realistic model of the data collected.

Following that method, we created 40 linear regression models-one for each of the imputed datasets. We then integrated across these datasets to pool the results and generate final estimates for the effects of each predictor. This method provides more robust estimates of the regression coefficients with less bias [66].

\section{Results}

5.1. Higher Perceived Design Thinking Ability Increases Senior Engineering Students' Interests in Designing Solutions Related to Energy Sustainability

To address the first research question, we analyzed whether engineering students with higher perceived design thinking ability were more likely to have interests in designing solutions related to energy sustainability. Figure 2 represents the coefficient density estimate for each design thinking trait. The Bayesian modeling framework represented in Figure 2 captures the uncertainty in model parameter estimates. This reflects the fact that each parameter in the model has uncertainty associated with its true value. Coefficient density estimate plots help represent the probability that each coefficient estimate takes on a specific value in the regression model. The uncertainty is represented in the figure with the grey region showing areas of higher and lower probability that the regression coefficient is in that range. More spread in the grey corresponds to more uncertainty about what the coefficient value might be. For example, the value of the coefficient corresponding to "I can personally contribute to a sustainable future" is most likely between 1.1 and 1.5. Positive coefficients suggest a positive association while negative ones express a negative association of these teaching strategies.

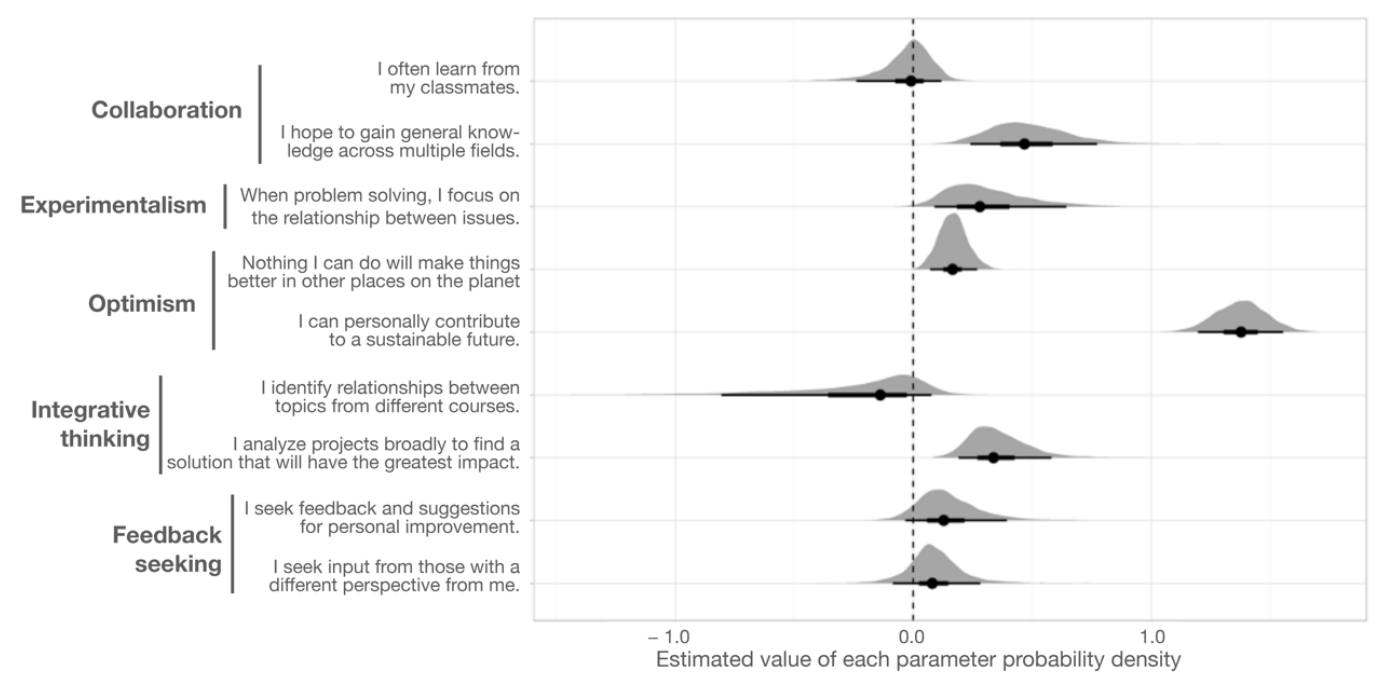

Figure 2. Halfeye plots of regression coefficient density estimates for the nine regression model parameters related to perceived design thinking traits of senior engineering students. The dot represents mean of the distribution, the bold line represents $50 \%$ of the probability density, the thinner line extends to the $90 \%$ density area. The shadow shows estimated probability density for each regression coefficient. Areas of higher density in the plot correspond to a higher relative likelihood for that value of the coefficient in the regression model. 
Overall, higher perceived design thinking abilities tend to be a positive predictor of students' willingness to engage in designing sustainable solutions. The exception is student response to "I identify relationships between topics from different courses", which is related to integrative thinking (see Figure 2). Students' perceived optimism in their capacity to contribute to a sustainable future is the highest predictor (beta $=1.38$; credibility interval $(\mathrm{CI})=1.16-1.58)$ of their interest in designing engineering solutions related to energy. Three other predictors are collaborative skills through the willingness to gain general knowledge across multiple fields (beta $=0.47 ; \mathrm{CI}=0.21-0.83$ ), integrative thinking represented by the ability to analyze projects broadly to find the most relevant solution (beta $=0.34 ; \mathrm{CI}=0.17-0.64$ ), and experimentalism expressed through students' capacity to focus on the relationship between issues when problem solving (beta $=0.28 ; \mathrm{CI}=0.05-0.71$ ).

\subsection{Active Learning Experiences Positively Influence Senior Engineering Students' Interests in} Designing Solutions Related to Energy Sustainability

To address the second research question, we explored to what extent active learning strategies in design courses influenced senior engineering students' interests in designing solutions related to energy consumption. Teaching strategies were classified as learning by imitation through a tutor's demonstration, collaborative learning during class discussion, peer learning, or group activities, and learning by doing through labs, projects, or individual work done in class. A higher frequency of those pedagogic experiences had a positive effect on students' interests in designing solutions related to energy sustainability, except for group activities. Figure 3 represents the coefficient density estimate for each teaching strategy parameter. Positive coefficients suggest a positive association while negative ones express a negative association of these teaching strategies. Working on labs or projects (learning by doing) was the strongest predictor (beta $=0.15, \mathrm{CI}:-0.01-0.35$ ) related to an increase in interest among students wanting to address design problems related to energy sustainability.

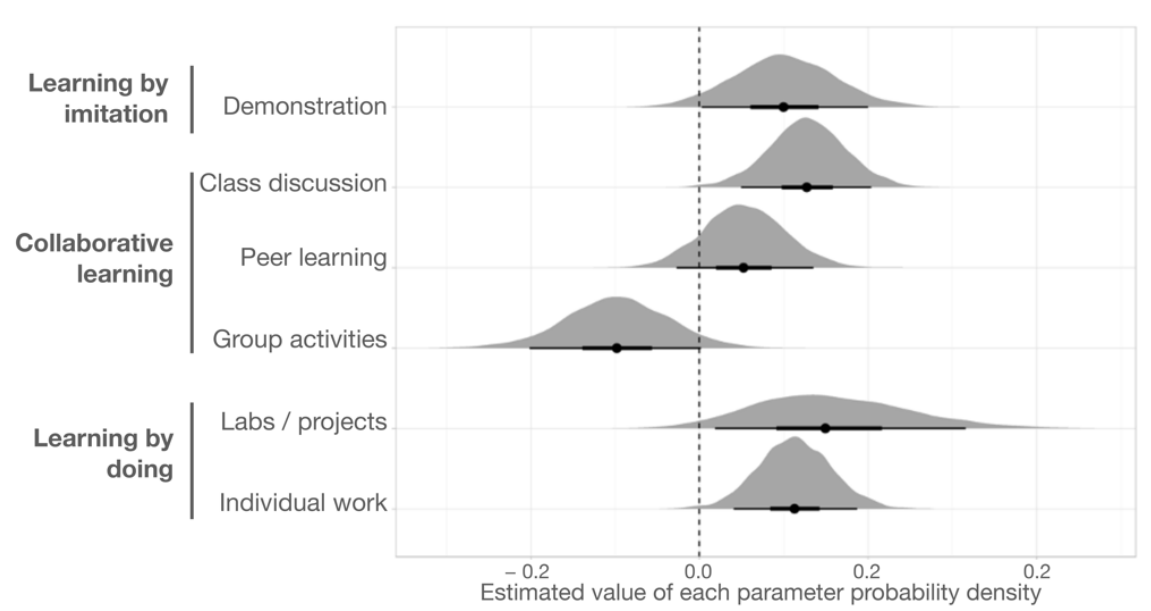

Figure 3. Halfeye plots of regression coefficient density estimates for the parameters related to active learning strategy in design courses. The dot represents mean of the distribution, the bold line represents $50 \%$ of the probability density, the thinner line extends to the $90 \%$ density area. The shadow shows estimated probability density for each regression coefficient. Areas of higher density in the plot correspond to a higher relative likelihood for that value of the coefficient in the regression model.

\section{Discussion}

Results from this study complement previous findings using this survey $[49,50]$ and deepen our understanding of factors that influence senior engineering students' interests in engaging in designing for a sustainable future. In this study, we evaluated participants ${ }^{\prime}$ interests in energy sustainability, namely (a) redesigning conventional processes in order to minimize energy consumption; (b) developing technologies that improve energy efficiency; (c) creating ways to reduce carbon dioxide emissions; and (d) working on renewable energy 
technologies, such as solar and wind power. All those sustainable design problems call for innovation and creativity to be addressed. To gain such knowledge, adequate teaching strategies have to be implemented in design courses.

\subsection{Design Thinking Skills to Address Sustainable Design Challenges Related to Energy Efficiency}

The findings from this study suggest that when students hold higher perceived design thinking skills, they maintain a greater interest to engage in designing for energy sustainability. Participants' perception of their design thinking skills relates to the notion of self-efficacy. Self-efficacy refers to one's assessment of their ability to engage in and achieve a given task [67]. It affects designers' behaviors based on their perceived abilities to perform a design task, making it a critical factor in engineering design [68]. Higher levels of creative self-efficacy tend to boost motivation, creative outcomes, and innovations $[67,69,70]$. Our results align with such findings as with higher perceived design thinking skills, participants felt confident in engaging in designing sustainable engineering solutions in their future career.

Design thinking traits with a higher positive effect on participants' motivation to tackle sustainable design challenges were their perceived contribution to a sustainable future (optimism), willingness to gain knowledge across multiple fields (collaboration), ability to analyze projects broadly to find a solution that will have the greatest impact (integrative thinking), and focusing on the relationship between issues when problem solving (experientialism).

These results are encouraging as such design thinking traits are a prerequisite for sustainable design. Collaboration between stakeholders from different fields is necessary as sustainable design involves multidisciplinarity and relies on the integration of multiple perspectives [5]. Focusing on the relationship between issues when problem solving and abilities to analyze projects broadly relate to features of systems thinking. The UN Sustainable Development Goals are presented at a system level and will rely on systems thinking to be addressed [1,4]. Design thinking traits related to a higher motivation to engage in sustainable design suit the shift needed from an unsustainable approach of "designing things right" to a sustainable approach of "designing the right thing" [3].

\subsection{Active Design Learning Strategies to Train Students for Sustainable Design Challenges Related to Energy Efficiency}

Engineering education nurtures engineering students' skills, know-how, interests, self-beliefs, and career goals [71]. Teaching design thinking [7,8], systems thinking [3,72,73], and sustainable design $[32,74,75]$ has become common in engineering curricula. These efforts from universities, department heads, and faculties are beneficial to the engineering community as students should graduate with the ability to make impactful changes in developing sustainable engineering solutions. In this study, the focus was set on pedagogic experiences of students in design courses in general not sustainable design per se. Our findings show that active learning strategies in design courses had a positive effect on senior students' motivation to engage in developing sustainable design solutions for energy efficiency. For example, learning by doing design through lab projects and individual work had a positive effect on participants' interest in engaging in sustainable design in their career. Project-based design learning improves knowledge retention in engineering education [7]. Through such active learning strategy, senior students can increase their self-belief in their abilities to address design challenges such as sustainability in engineering solutions for energy efficiency.

Collaboration is key in sustainable design as complex problems cannot be solved in disciplinary silos [4]. Out of the three collaborative learning activities in design courses, two (peer learning and class discussion) had a positive effect on participants' interest in sustainable design. Surprisingly, group activities had a negative effect on senior students' interest in sustainable design. It implies that senior students that worked less often in groups hold higher interest in engaging in sustainable design. 


\subsection{Implications for Engineering Design Education}

A main limitation of the study presented is that the survey did not target design courses that specifically implemented the development of sustainable engineering solutions. The survey instrument also did not include a section on course content. However, design skills and innovation, whether applied to sustainable design or not, are needed to implement sustainable development goals, which support the relevance of this study. Our findings shed light on the positive relationship between design thinking traits and willingness to engage in sustainable design challenges. Therefore, design education becomes a cornerstone in educating engineers with skills relevant for the practices needed to address the UN Sustainable Development Goals [1]. A sustainability rubric, final degree projects, a flipped classroom, project-based learning, including inventive problem solving, an internship, and a laboratory experiment, among others, are suitable candidates to apply the UN Sustainable Development Goals (SDG) within engineering courses [75]. By implementing such strategies, engineering education can begin to influence future professionals' motivation to address multiple dimensions of sustainable development within their career. Integrating content (sustainable project development in a design course) and pedagogical strategies (active learning through hands-on projects) appear as a suitable way to move forward, toward that goal. In doing so, students can develop knowledge that aligns with engineers' competencies expectations to analyze complex problems while considering sustainable outcomes for our society [12].

In future work, we intend to target design courses focusing on sustainable design to gain a better understanding of the relationship between pedagogic content, pedagogic strategies, and design thinking traits in promoting career interests centered on implementing the UN Sustainable Development Goals (SDG). Future research can also begin to extend this study to include students from outside of our national sample in the United States. The findings that (1) higher perceived design thinking ability increases senior engineering students' interests in designing solutions related to energy sustainability and (2) active learning experiences positively influence senior engineering students' interests in designing solutions related to energy sustainability are not country-specific. However, the total number of students who hold high perceived design thinking abilities, the percent of students exposed to active learning in design education, and student interest in energy sustainability may vary. Exploring differences in educational systems and the effect of these differences on students' interest in designing solutions related to energy sustainability could help highlight countries and institutions well-equipped to lead in global sustainable design in the future.

\section{Conclusions}

This study focused on the impact of perceived design thinking traits and active design learning strategies to increase senior engineering students' motivation to engage in energy sustainability in their career. A representative sample of senior engineering students in the United States $(n=4364)$ participated in the study (for more details about survey distribution and validation see $[49,50])$. Students were asked about their interests in addressing the following sustainable design problems in their future career: (a) redesigning conventional processes in order to minimize energy consumption; (b) developing technologies that improve energy efficiency; (c) creating ways to reduce carbon dioxide emissions; and (d) working on renewable energy technologies, such as solar and wind power. Findings demonstrated that participants' motivation to engage in sustainable design increase with higher perceived design thinking traits (i.e., integrative feedback or collaboration) and when they benefitted from active learning strategies in design courses (i.e., learning by doing).

These findings support the importance of teaching design thinking in engineering courses to empower future engineers in their ability to address sustainable challenges through design and innovation. Engineers play an important role in implementing the UN Sustainable Development Goals, aiming at providing a more sustainable environment for 
future generations. Relying on design thinking, creativity, and innovation, skills that can be learned in engineering education, future engineers can develop sustainable engineering solutions restorative to the environment.

Author Contributions: The paper was conceptualized by J.M. and written by all authors. The methodology was led by T.S. and analysis was led by A.K. All authors have read and agreed to the published version of the manuscript.

Funding: This material is based upon work supported by the National Science Foundation under Grant No. 1635534 and 1635204. Any opinions, findings, and conclusions or recommendations expressed in this material are those of the author(s) and do not necessarily reflect the views of the National Science Foundation.

Institutional Review Board Statement: The study was conducted according to the guidelines of the Declaration of Helsinki, and approved by the Institutional Review Board of Virginia Tech (protocol code 16-631 approved on the 16 June 2021).

Informed Consent Statement: Consent was implied with the return of the completed questionnaire.

Data Availability Statement: Data are contained within the article. Additional data are available on request to the corresponding author.

Acknowledgments: We would like to thank the students who participated in the research by completing the survey.

Conflicts of Interest: The authors declare no conflict of interest.

\section{References}

1. United Nations. The Sustainable Development Goals Report; United Nations Publications: New York, NY, USA, 2020.

2. Cucuzzella, C. Creativity, sustainable design and risk management. J. Clean. Prod. 2016, 135, 1548-1558. [CrossRef]

3. Cardenas, C.; Sosa, R.; Moysen, R.; Martinez, V. Sustaining sustainable design through systemic thinking. Int. J. Eng. Educ. 2010, 29, 287-292.

4. Jowitt, P.W. Systems and sustainability. Civ. Eng. Environ. Syst. 2020, 37, 253-263. [CrossRef]

5. Klotz, L.; Weber, E.; Johnson, E.; Shealy, T.; Hernandez, M.; Gordon, B. Beyond rationality in engineering design for sustainability. Nat. Sustain. 2018, 1, 225-233. [CrossRef]

6. Daly, S.R.; Mosyjowski, E.A.; Seifert, C.M. Teaching creativity in engineering courses. J. Eng. Educ. 2014, 103, 417-449. [CrossRef]

7. Dym, C.L.; Agogino, A.M.; Eris, O.; Frey, D.D.; Leifer, L.J. Engineering design thinking, teaching, and learning. J. Eng. Educ. 2005, 94, 103-120. [CrossRef]

8. Bertoni, A. Introducing value driven design in engineering education: Teaching the use of value models in preliminary design Int. J. Technol. Des. Educ. 2020, 30, 531-552. [CrossRef]

9. Froyd, J.E.; Wankat, P.C.; Smith, K.A. Five major shifts in 100 years of engineering education. Proc. IEEE 2012, 100, 1344-1360. [CrossRef]

10. Howe, S. Where are we now? Statistics on capstone courses nationwide. Adv. Eng. Educ. 2010, 2, 1-27.

11. Crawley, E.F.; Malmqvist, J.; Östlund, S.; Brodeur, D.R.; Edström, K. The CDIO Approach. In Rethinking Engineering Education: The CDIO Approach; Crawley, E.F., Malmqvist, J., Östlund, S., Brodeur, D.R., Edström, K., Eds.; Springer International Publishing: Cham, Switzerland, 2014; pp. 11-45. ISBN 978-3-319-05561-9.

12. IAE Graduate Attributes and Professional Competences. The International Engineering Alliance. 2021. Available online: https:/ / www.ieagreements.org/ (accessed on 11 January 2021).

13. Vygotsky, L. Mind in Society: The Development of Higher Psychological Processes; Harvard University Press: Cambridge, MA, USA, 1978.

14. Lave, J.; Wenger, E. Situated Learning: Legitimate Peripheral Participation; Learning in Doing: Social, Cognitive and Computational Perspectives; Cambridge University Press: Cambridge, UK, 1991.

15. Kolb, D.A. Experiential Learning: Experience as the Source of Learning and Development; Prentice Hall: Englewood Cliffs, NJ, USA, 1984.

16. Nespoli, O.G.; Hurst, A.; Gero, J.S. Exploring tutor-student interactions in a novel virtual design studio. Des. Stud. 2021, 75, 101019. [CrossRef]

17. Lucchi, E.; Delera, A.C. Enhancing the historic public social housing through a user-centered design-driven approach. Buildings 2020, 10, 159. [CrossRef]

18. Pahl, G.; Beitz, W.; Feldhusen, J.; Grote, K. Engineering Design: A Systematic Approach, 3rd ed.; Springer: London, UK, 2007; ISBN 978-1-84628-318-5.

19. Bucciarelli, L.L. An Ethnographic perspective on engineering design. Des. Stud. 1988, 9, 159-168. [CrossRef]

20. Schön, D. The Reflective Practitioner: How Professionals Think in Action; Temple Smith: London, UK, 1983. 
21. Lawson, B.; Dorst, K. Design Expertise; Routledge: Oxfordshire, UK, 2009.

22. Dorst, K. The core of 'design thinking' and its application. Des. Stud. 2011, 32, 521-532. [CrossRef]

23. Magistretti, S.; Ardito, L.; Messeni Petruzzelli, A. Framing the microfoundations of design thinking as a dynamic capability for innovation: Reconciling theory and practice. J. Prod. Innov. Manag. 2021. [CrossRef]

24. Brown, T. Design thinking. Harv. Bus. Rev. 2008, 86, 84-93.

25. Carlgren, L.; Rauth, I.; Elmquist, M. Framing design thinking: The concept in idea and enactment: Creativity and innovation management. Creat. Innov. Manag. 2016, 25, 38-57. [CrossRef]

26. Brundtland, G.H. Our Common Future; Oxford University Press: Oxford, UK, 1987.

27. National Academy of Engineering NAE. Grand Challenges for Engineering; National Academy of Engineering NAE: Washington, DC, USA, 2008; p. 56. Available online: http://www.engineeringchallenges.org/challenges.aspx (accessed on 11 January 2021).

28. National Academy of Engineering (Ed.) Educating the Engineer of 2020: Adapting Engineering Education to the New Century; National Academies Press: Washington, DC, USA, 2005; ISBN 978-0-309-09649-2.

29. Lawson, B. How Designers Think: The Design Process Demystified, 4th ed.; Elsevier/Architectural Press: Amsterdam, The Netherlands, 2006; ISBN 978-0-7506-6077-8.

30. Collado-Ruiz, D.; Ostad-Ahmad-Ghorabi, H. Influence of environmental information on creativity. Des. Stud. 2010, 31, 479-498. [CrossRef]

31. Maccioni, L.; Borgianni, Y.; Pigosso, D.C.A. Can the choice of eco-design principles affect products' success? Des. Sci. 2019, 5, e25. [CrossRef]

32. McDonough, W.; Braungart, M. Cradle to Cradle: Remaking the Way We Make Things; North Point Press: New York, NY, USA, 2002.

33. Allenby, B.; Murphy, C.; Allen, D.; Davidson, C. Sustainable engineering education in the United States. Sustain. Sci. 2009, 4, 7-15. [CrossRef]

34. Mulder, K.F.; Segalàs, J.; Ferrer-Balas, D. How to educate engineers for/in sustainable development: Ten years of discussion, remaining challenges. Int. J. Sustain. High. Educ. 2012, 13, 211-218. [CrossRef]

35. Daly, S.R.; Christian, J.L.; Yilmaz, S.; Seifert, C.M.; Gonzalez, R. Assessing design heuristics for idea generation in an introductory engineering course. Int. J. Eng. Educ. 2012, 28, 463-473.

36. Mills, J.; Treagust, D. Engineering education-Is problem-based or project-based learning the answer? Australas. J. Eng. Educ. 2003, 3, 2-16.

37. Blizzard, J.L.; Klotz, L.E. A framework for sustainable whole systems design. Des. Stud. 2012, 33, 456-479. [CrossRef]

38. Morris, R.; Childs, P.; Hamilton, T. Sustainability by design: A reflection on the suitability of pedagogic practice in design and engineering courses in the teaching of sustainable design. Eur. J. Eng. Educ. 2007, 32, 135-142. [CrossRef]

39. Zancul, E.D.S.; Blikstein, P.; Majzoub, G.G.; Dalmon, D.L. An empirical study on design-based vs. traditional approaches in capstone courses in engineering education. Int. J. Eng. Educ. 2017, 33, 1543-1560.

40. Guerra, M.; Shealy, T. Teaching user-centered design for more sustainable infrastructure through role-play and experiential learning. J. Prof. Issues Eng. Educ. Pract. 2018, 144, 05018016:1-05018016:10. [CrossRef]

41. Schön, D. Educating the Reflective Practitionner; Jossey-Bass Publishers: San Fransisco, CA, USA, 1987.

42. Schön, D.A. The Design Studio; RIBA: London, UK, 1985.

43. Boudhraa, S.; Dorta, T.; Milovanovic, J.; Pierini, D. Co-ideation critique unfolded: An exploratory study of a co-design studio 'crit' based on the students' experience. CoDesign 2019, 15, 119-138. [CrossRef]

44. Adams, R.S.; Forin, T.; Chua, M.; Radcliffe, D. Characterizing the work of coaching during design reviews. Des. Stud. 2016, 45, 30-67. [CrossRef]

45. Yilmaz, S.; Daly, S.R. Feedback in concept development: Comparing design disciplines. Des. Stud. 2016, 45, 137-158. [CrossRef]

46. Mewburn, I. Lost in translation: Reconsidering reflective practice and design studio pedagogy. Arts Humanit. High. Educ. 2012, 11,363-379. [CrossRef]

47. Dutton, T.A. Design and studio pedagogy. J. Archit. Educ. 1987, 41, 16. [CrossRef]

48. Sidawi, B. The role of healthy social interaction and communications in provoking creativity in the design studio. High. Educ. Pedagog. 2016, 1, 64-81. [CrossRef]

49. Watson, M.K.; Barrella, E.; Wall, T.; Noyes, C.; Rodgers, M. Comparing measures of student sustainable design skills using a project-level rubric and surveys. Sustainability 2020, 12, 7308. [CrossRef]

50. Mesa, J.; Esparragoza, I.; Maury, H. Sustainability in Engineering Education: A Literature Review of Case Studies and Projects. In Proceedings of the 15th LACCEI International Multi-Conference for Engineering, Education, and Technology: "Global Partnership for Development and Engineering Education", Latin American and Caribbean Consortium of Engineering Institutions, Boca Raton, FL, USA, 19-21 July 2017.

51. Bielefeldt, A. Pedagogies to achieve sustainability learning outcomes in civil and environmental engineering students. Sustainability 2013, 5, 4479-4501. [CrossRef]

52. Wickham, H. Ggplot2: Elegant Graphics for Data Analysis; Use R!; Springer: New York, NY, USA, 2009; ISBN 978-0-387-98141-3.

53. R Core Team, R. A Language and Environment for Statistical Computing; Computer Software; R Foundation for Statistical Computing: Vienna, Austria, 2019. 
54. Shealy, T.; Godwin, A.; Gardner, H. Survey Development to Measure the Gap Between Student Awareness, Literacy, and Action to Address Human-Caused Climate Change. In Proceedings of the 2017 ASEE Annual Conference \& Exposition Proceedings, ASEE Conferences, Columbus, OH, USA, 24-28 June 2017.

55. Katz, A.; Shealy, T.; Godwin, A. Civil Engineering Students' Beliefs about the Technical and Social Implications of Global Warming and When Global Warming Will Impact Them Personally and Others. In Proceedings of the 2020 ASEE Virtual Annual Conference Content Access Proceedings, ASEE Conferences, Virtual On-line, 22-26 June 2020.

56. Byrne, B.M. Structural Equation Modeling with EQS and EQS/Windows: Basic Concepts, Applications, and Programming; SAGE Publications Inc.: New York, NY, USA, 1994.

57. Schumacker, R.; Lomax, R. A Beginner's Guide to Structural Equation Modeling; Lawrence Erlbaum Associates: Mahwah, NJ, USA, 2004.

58. Xia, Y.; Yang, Y. RMSEA, CFI, and TLI in structural equation modeling with ordered categorical data: The story they tell depends on the estimation methods. Behav. Res. 2019, 51, 409-428. [CrossRef] [PubMed]

59. Blizzard, J.; Klotz, L.; Potvin, G.; Hazari, Z.; Cribbs, J.; Godwin, A. Using survey questions to identify and learn more about those who exhibit design thinking traits. Des. Stud. 2015, 38, 92-110. [CrossRef]

60. Brown, T.; Wyatt, J. Design Thinking for Social Innovation. Stanf. Innov. Rev. 2010, 12, 31-35. [CrossRef]

61. Cross, N. Designerly Ways of Knowing; Springer: London, UK, 2006.

62. Coleman, E.; Shealy, T.; Grohs, J.; Godwin, A. Design thinking among first-year and senior engineering students: A cross-sectional, national study measuring perceived ability. J. Eng. Educ. 2019, 109, 72-87. [CrossRef]

63. Little, R.J.A.; Rubin, D.B. Statistical Analysis with Missing Data, 2nd ed.; Wiley: New York, NY, USA, 2002.

64. Van Buuren, S.; Groothuis-Oudshoorn, K. Mice: Multivariate imputation by chained equations in R. J. Stat. Soft. $2011,45,1-67$. [CrossRef]

65. Bürkner, P.-C. Brms: An R package for Bayesian multilevel models using stan. J. Stat. Soft. 2017, 80, 1-28. [CrossRef]

66. Collins, L.M.; Schafer, J.L.; Kam, C.-M. A comparison of inclusive and restrictive strategies in modern missing data procedures. Psychol. Methods 2001, 6, 330-351. [CrossRef]

67. Bandura, A. Self-Efficacy; Wiley: New York, NY, USA, 1994.

68. Hutchison, M.A.; Follman, D.K.; Sumpter, M.; Bodner, G.M. Factors Influencing the self-efficacy beliefs of first-year engineering students. J. Eng. Educ. 2006, 95, 39-47. [CrossRef]

69. Tierney, P.; Farmer, S. Creative self-efficacy: Its potential antecedents and relationship to creative performance. Acad. Manag. J. 2002, 45, 1137-1148.

70. Zhang, X.; Bartol, K. Linking empowering leadership and employee creativity: The influence of psychological empowerment, intrinsic motivation, and creative process engagement. Acad. Manag. J. 2010, 53, 107-128. [CrossRef]

71. Lent, R.W.; Sheu, H.-B.; Singley, D.; Schmidt, J.A.; Schmidt, L.C.; Gloster, C.S. Longitudinal relations of self-efficacy to outcome expectations, interests, and major choice goals in engineering students. J. Vocat. Behav. 2008, 73, 328-335. [CrossRef]

72. Hayden, N.J.; Rizzo, D.M.; Dewoolkar, M.M.; Oka, L.; Neumann, M. Incorporating Systems Thinking and Sustainability within Civil and Environmental Engineering Curricula at UVM. In Proceedings of the ASEE Northeast Regional Conference Proceedings, Rochester Institute of Technology, Rochester, NY, USA, 26-27 March 2010.

73. Lund, J. Systems engineering knowledge and skills for water and environmental problems. Civ. Eng. Environ. Syst. 2020, 37, 183-196. [CrossRef]

74. Fourati-Jamoussi, F.; Dubois, M.J.F.; Chedru, M.; Belhenniche, G. Education for sustainable development and innovation in engineering school: Students' perception. Sustainability 2021, 13, 6002. [CrossRef]

75. Romero, S.; Aláez, M.; Amo, D.; Fonseca, D. systematic review of how engineering schools around the world are deploying the 2030 agenda. Sustainability 2020, 12, 5035. [CrossRef] 